\title{
EVALUASI KEANDALAN PEMBANGKIT LISTRIK TENAGA SURYA YANG TERHUBUNG KE GRID
}

\author{
Adrianti \\ Jurusan Teknik Elektro, Fakultas Teknik, Universitas Andalas \\ Corresponding author, e-mail : adrianti@ft.unand.ac.id
}

\begin{abstract}
Abstrak - Keandalan Pembangkit Listrik Tenaga Surya (PLTS) dipengaruhi oleh dua jenis permasalahan yaitu ketersediaan cahaya matahari dan kesiapan peralatan PLTS untuk membangkitkan daya listrik. Peralatan PLTS terdiri dari perangkat elektronik yang ditempatkan di luar ruangan dan mengalami berbagai kondisi cuaca, sehingga perlu dievaluasi keandalannya dalam membangkitkan daya listrik. Pada tulisan ini dilakukan evaluasi keandalan PLTS dari segi kesiapaan peralatan untuk membangkitkan daya. Metoda Bayesian Network digunakan dalam menghitung probabilitas PLTS untuk menghasilkan daya penuh dan tidak penuh (reduced output). Hasil yang diperoleh menunjukkan probabilitas kondisi tanpa output daya pada PLTS dua kali lebih sedikit dibandingan reduced output. Secara keseluruhan keandalan PLTS cukup baik.
\end{abstract}

\section{Kata Kunci : PLTS, keandalan dan Bayesian Network}

\begin{abstract}
The reliability of a photovoltaic system is influenced by two kind of challenges i.e. the availability of the sunlight and the readiness of the PV system components to generate power. A PV system consists of electronic components which are placed outdoors and suffered harsh weather, therefore its reliability needs to be evaluated. Bayesian Networks are utilized to calculate the probabilities of having full and reduced power output of the PV system. The study results show that the reduced power output state of the PV system is twice more likely than the no-output state. In general, the reliability of the PV system is relatively good.
\end{abstract}

Keywords : Photovoltaic, Reliability and Bayesian Network

Copyright $\odot 2016$ JNTE. All rights reserved

\section{PENDAHULUAN}

Pembangkit listrik tenaga surya (PLTS) merupakan salah satu tipe pembangkit listrik terbaharukan yang potensial di negara tropis seperti Indonesia. Dalam Renstra Kementerian Energi dan Sumber Daya Mineral tahun 2015 diproyeksikan 260,3 MW daya terpasang PLTS akan melayani konsumen di tahun 2019 [1]. Dengan kapasitas PLTS yang besar tersebut, keandalan sistem tenaga listrik di Indonesia akan dipengaruhi oleh keandalan PLTS. Sehingga analisa keandalan PLTS penting untuk dikaji.

Keandalan sebuah PLTS dalam menyediakan daya listrik dikaji dalam dua aspek yaitu keandalan sehubungan dengan variasi output PLTS karena variasi cuaca dan keandalan peralatan/komponen PLTS untuk beroperasi. PLTS terdiri dari komponen-komponen elektronik yang dipasang di luar ruangan dan terpapar berbagai kondisi cuaca. Hal ini dapat memicu kerusakan pada komponen yang selanjutnya akan mempengaruhi performa PLTS.

Harga komponen PLTS masih belum ekonomis jika dibandingkan dengan pembangkit konvensional sehingga harga per Kwh listrik yang dihasilkannya masih cukup mahal. Dalam [2] dinyatakan bahwa PLTS yang terhubung ke grid merupakan salah satu solusi untuk menekan biaya pengadaan PLTS mengingat harga baterai yang mahal. Karena itu dalam studi ini difokuskan pada PLTS yang terhubung ke grid.

Dalam tulisan ini akan dibahas analisa keandalan PLTS sebagai akumulasi keandalan dari masing-masing komponennya. Perhitungan dilakukan menggunakan metoda Bayesian Network. Metoda Bayesian Network adalah metoda perhitungan probabilitas yang sudah banyak diaplikasikan diberbagai bidang untuk tujuan prediksi maupun diagnosis [3].

Tulisan ini akan dimulai dengan pengantar singkat tentang teori keandalan sistem, dilanjutkan dengan penjelasan singkat tentang metoda Bayesian Network. Selanjutnya 
pembahasan tentang komponen-komponen dari suatu PLTS dan moda kerusakannya (failure mode). Kemudian, sebagai ilustrasi, perhitungan keandalan dari sebuah PLTS yang terhubung ke grid diketengahkan. Tulisan akan ditutup dengan kesimpulan dan saran.

\section{PENGANTAR KEANDALAN SISTEM}

Keandalan adalah probabilitas bahwa sebuah item (komponen/peralatan/sistem) akan beroperasi tanpa kerusakan untuk suatu jangka waktu yang ditetapkan, dibawah kondisi tertentu [4]. Sehingga keandalan adalah suatu cara untuk mengukur probabilitas kesuksesan suatu item sepanjang waktu tertentu. Sebuah sistem biasanya terdiri dari gabungan beberapa item/komponen yang bekerja bersama-sama. Akibatnya, keandalan sebuah sistem merupakan akumulasi keandalan dari komponenkomponennya.

Secara garis besar, langkah-langkah perhitungan keandalan sebuah sistem adalah:

1. mengidentifikasi potensi moda kerusakan pada tiap komponen dari sistem

2. menganalisa efek setiap moda kerusakan komponen terhadap kinerja sistem dan menetapkan moda kerusakan dari sistem

3. mengumpulkan data failure rate dari setiap moda kerusakan komponen dan menghitung probabilitas terjadinya moda kerusakan tersebut.

4. melakukan perhitungan probabilitas terjadinya moda kerusakan sistem dengan menggunakan metoda-metoda probabilitas.

Untuk failure rate yang konstan, probabilitas terjadinya suatu moda kerusakan sebuah komponen dapat dihitung sebagai:

$$
F(t)=1-e^{-\lambda t}
$$

Dimana:

$\lambda=$ failure rate $=$ jumlah kerusakan karena moda tersebut per satuan waktu

$\mathrm{t}=$ jangka waktu untuk analisa kerusakan (jam/hari/tahun dan lain-lain).

Jika ada n moda kerusakan dari sebuah komponen dan setiap moda memiliki probabilitas kerusakan $F_{i}$ maka probabilitas kesuksesan dari komponen tersebut adalah

$$
R(t)=1-\sum_{1}^{n} F_{i}
$$

Setelah setiap moda kerusakan dari semua komponen dihitung probabilitasnya, maka probabilitas moda kerusakan dari sistem sebagai suatu kesatuan dapat dihitung. Ada banyak metoda yang dapat digunakan seperti reliability networks, fault tree, Markov chain dan Bayesian Network. Untuk perhitungan keandalan PLTS ini akan digunakan metoda Bayesian Network. Metoda ini dipilih karena memiliki kemampuan yang cocok untuk aplikasi keandaan PLTS seperti: komponen-komponen memiliki lebih dari satu moda kerusakan sehingga tidak efisien jika menggunakan metoda reliability networks dan fault tree; PLTS memiliki banyak komponen dan banyak moda sehingga jika menggunakan Markov chain, maka sistem Markovnya akan menjadi sangat besar sehingga lebih sulit untuk diselesaikan.

Di bagian berikutnya akan dibahas secara singkat tentang metoda Bayesian Network.

\section{BAYESIAN NETWORK}

Bayesian Network yang juga dikenal dengan Bayesian Belief Network, adalah salah satu metoda perhitungan probabilitas yang telah diaplikasikan untuk keandalan software, system pencarian kerusakan, pemodelan untuk pemeliharaan (maintenance), system expert untuk diagnosa penyakit serta prediksi lalu lintas udara $[5,6]$. Bayesian Network telah menunjukkan kemampuannya yang sangat baik untuk perhitungan probabilitas.

Bayesian Network dibentuk dari dua tipe analisa yaitu analisa kualitatif dan analisa kuantitatif. Analisa kualitatif berupa pembentukan graph acyclic berarah yang merepresentasikan hubungan logis antar variabel dalam system. Contoh sebuah graph acyclic berarah ditunjukkan oleh Gambar 1. Garis panah yang menghubungkan dua buah node melambangkan hubungan sebab akibat diantara kedua variabel yang dihubungkannya, yaitu dari penyebab ke akibat. Node dimana garis panah berawal disebut parent node dan node dimana garis panah berakhir disebut descendant node. Node yang tidak memiliki parent node disebut root node.

Kuantitatif analisis berisikan nilai probabilitas awal untuk root node dan Conditional Probability Table (CPT) untuk node lainnya. Nilai probabilitas awal merepresentasikan kemungkinan terjadinya 
moda/state dari root node, sementara CPT merepresentasikan probabiltas kemunculan state dari descendant node untuk setiap state dari parent node.

\begin{tabular}{|c|c|}
\hline$T$ & $F$ \\
\hline 0.5 & 0.5 \\
\hline
\end{tabular}

\begin{tabular}{|c|c|c|}
\hline$A$ & $B$ & $C$ \\
\hline 0.7 & 0.2 & 0.1 \\
\hline
\end{tabular}

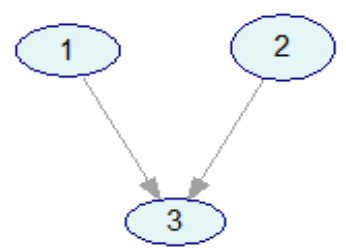

Gambar 1. Sebuah Graph dari Bayesian Network dan nilai probabilitas awalnya

Tabel 1. Conditional Probability Table (CPT) dari node 3 di Gambar 1.

\begin{tabular}{|c|c|c|c|c|c|c|}
\hline Node 1 & \multicolumn{3}{|c|}{ T } & \multicolumn{3}{c|}{ F } \\
\hline Node 2 & A & B & C & A & B & C \\
\hline G & 1 & 0.5 & 0.2 & 0 & 0.9 & 0.5 \\
\hline H & 0 & 0.3 & 0.3 & 0.5 & 0.1 & 0.5 \\
\hline J & 0 & 0.2 & 0.5 & 0.5 & 0 & 0 \\
\hline
\end{tabular}

Setiap node memiliki dua atau lebih state. Misalnya digambar 1 , node 1 memiliki dua state ( $\mathrm{T}$ dan $\mathrm{F}$ ), sementara node 2 memiliki tiga state (A,B dan C). Probabititas kemunculan setiap state dari node 1 dan 2 di tunjukkan oleh tabel probabilitas di Gambar 1. Probabilitas kemunculan states dari node 3 ditunjukkan oleh CPT di tabel 1. Sebuah CPT menunjukkan conditional probability kemunculan state-state yang didasarkan pada state dari parent nodes. Misalnya dari tabel 1, jika node 1 dalam state $\mathrm{F}$ dan node 2 dalam state $\mathrm{B}$, maka probabilitas kemunculan node 3 dengan state $\mathrm{G}, \mathrm{H}$ dan $\mathrm{J}$ secara berturut-turut adalah 0,$9 ; 0,1$ dan 0 . Jumlah probabilitas untuk semua state harus selalu satu.

Probabilitas keunculan sebuah descendant $\mathrm{x}$ dihitung sebagai jumlah probability dari semua state dari parentnya ((yi):

$$
P(x)=\sum_{i} P\left(x \mid y_{i}\right) P\left(y_{i}\right)
$$

Misalnya, probabilitas node 3 (N3) berada di state $\mathrm{H}$ dihitung sebagai total penjumlahan dari perkalian conditional probability and parent states di node $2(\mathrm{~N} 2)$ dan node $1(\mathrm{~N} 1)$ :
$P(N 3=H)=$

$\sum_{i} P\left(N 3=H \mid\right.$ parents of $\left.N 3_{i}\right) P\left(\right.$ parents of $\left.N 3_{i}\right)$

$P(N 3=H)=P(N 3=H \mid N 1=T, N 2=A) P(N 1=$ T) $P(N 2=A)+P(N 3=H \mid N 1=T, N 2=B) P(N 1=$

T) $P(N 2=B)+P(N 3=H \mid N 1=T, N 2=C) P(N 1=$

T) $P(N 2=C)+P(N 3=H \mid N 1=F, N 2=A) P(N 1=$

F) $P(N 2=A)+P(N 3=H \mid N 1=F, N 2=B) P(N 1=$

F) $P(N 2=B)+P(N 3=H \mid N 1=F, N 2=C) P(N 1=$

F) $P(N 2=C)$

$P(3=H)=0+(0.3 \times 0.5 \times 0.2)+(0.3 \times 0.5 \times 0.1)+$ $(0.5 \times 0.5 \times 0.7)+(0.1 \times 0.5 \times 0.2)+(0.5 \times 0.5 \times$

$0.1)$

$P(3=H)=0.255$

Keuntungan penggunaan Beyesian Network terletak pada kemampuan metoda ini untuk merepresentasikan banyak state dari sebuah variabel, dapat memodelkan berbagai macam hubungan antar variabel, dapat memodelkan variabel yang dipengaruhi oleh variabel lain (dependent variable) dan kemampuan untuk mengatasi keterbatasan data statistic [3].

\section{TIPIKAL KOMPONEN DARI SUATU PLTS}

PLTS yang terhubung ke grid minimal memiliki komponen-komponen seperti yang ditunjukkan oleh gambar 2 [7]. Setiap komponen PLTS dapat mengalami berbagai jenis kerusakan yang berpengaruh terhadap kinerja PLTS. Jenis komponen-komponen dan moda kerusakannya serta efek kerusakan tersebut terhadap kinerja PLTS disarikan di Tabel 2 [8].

Berdasarkan efek kerusakan komponenkomponen terhadap kinerja PLTS, dapat dikategorikan 3 state dari sebuah PLTS, yaitu:

1. Kondisi normal dimana PLTS dapat mensuplai daya penuh

2. Kondisi no-output, dimana PLTS sama sekali tidak dapat beroperasi membangkitkan daya listrik.

3. Kondisi reduced-output, dimana PLTS hanya mampu berproduksi tetapi outpunya lebih rendah dari ratingnya.

Pada Tabel 2 juga diberikan data failure rate dari tiap moda kerusakan. Data-data tersebut umumnya merupakan hasil pengumpulan data lapangan yang di tulis dalam referensi $[7,8]$.

Berdasarkan data failure rate tersebut, terlihat bahwa inverter memiliki frekuensi kerusakan yang paling tinggi dibandingkan dengan komponen lainnya. Ditambah lagi 
kerusakan inverter ini umumnya menyebabkan kondisi no-ouput bagi PLTS. Penyebab kerusakan inverter ini antara lain : software pengontrolan, pengaruh cuaca buruk, kerusakan isolasi, petir, tegangan lebih dan lain-lain $[8,11]$.

Kerusakan modul sel surya umumnya memiliki frekuensi yang relatif lebih kecil. Akan tetapi kerusakannya sering tidak terdeteksi, terutama untuk PLTS besar yg memilik array modul yang luas. Ditambah lagi dengan pengaruh kerusakan sebagian kecil modul terhadap daya keluaran PLTS yang sering tidak signifikan. Kerusakan modul dapat disebabkan oleh pengotoran permukaan oleh debu, terlindungi oleh suatu bayangan benda, hubung singkat, arc, penuaan dan lain-lain.

\section{PERHITUNGAN KEANDALAN PLTS}

Metoda perhitungan keandalan suatu PLTS ditunjukkan oleh algoritma berikut:

1. Mulai

2. Buat rangkaian listrik dari PLTS yang akan dievaluasi

3. Buat list semua komponen dari PLTS tersebut

4. Evaluasi semua moda kerusakan yang dapat terjadi pada komponen PLTS.

5. Evaluasi efek setiap moda kerusakan komponen terhadap kinerja PLTS, dalam hal ini pengaruh daya yang dibangkitkan.
6. Kumpulkan data failure rate dari setiap moda kerusakan.

7. Tetapkan moda/state kerusakan sistem PLTS secara keseluruhan berdasarkan efek kerusakan komponen-komponennya.

8. Susun graph sebab akibat dari Bayesian Network untuk perhitungan keandalan PLTS

9. Inputkan data probabilitas untuk masingmasing node dari Bayesian Network.

10. Lakukan perhitungan probabilitas untuk sistem PLTS.

11. Uji kebenaran Bayesian Network yang sudah disusun. Jika salah kembali ke h, jika benar ke 1 .

12. Selesai

PLTS yang dievaluasi (gambar 2) memiliki 5 string yang terhubung paralel dan setiap string terdiri atas 4 modul yang terhubung seri. Module yang digunakan adalah 48 Volt DC dengan daya 100 Watt.

Langkah 1 sampai 7 dari algoritma evaluasi keandalan PLTS sudah dibahas pada bagian sebelumnya, karena itu dibagian ini akan dilanjutkan dengan penyusunan diagram Bayesian Network dari PLTS digambar 2. Perhitungan dengan metoda Bayesian Network dilakukan dengan menggunakan software GeNIe yang dikembangkan oleh Universitas Pittsburgh [12].

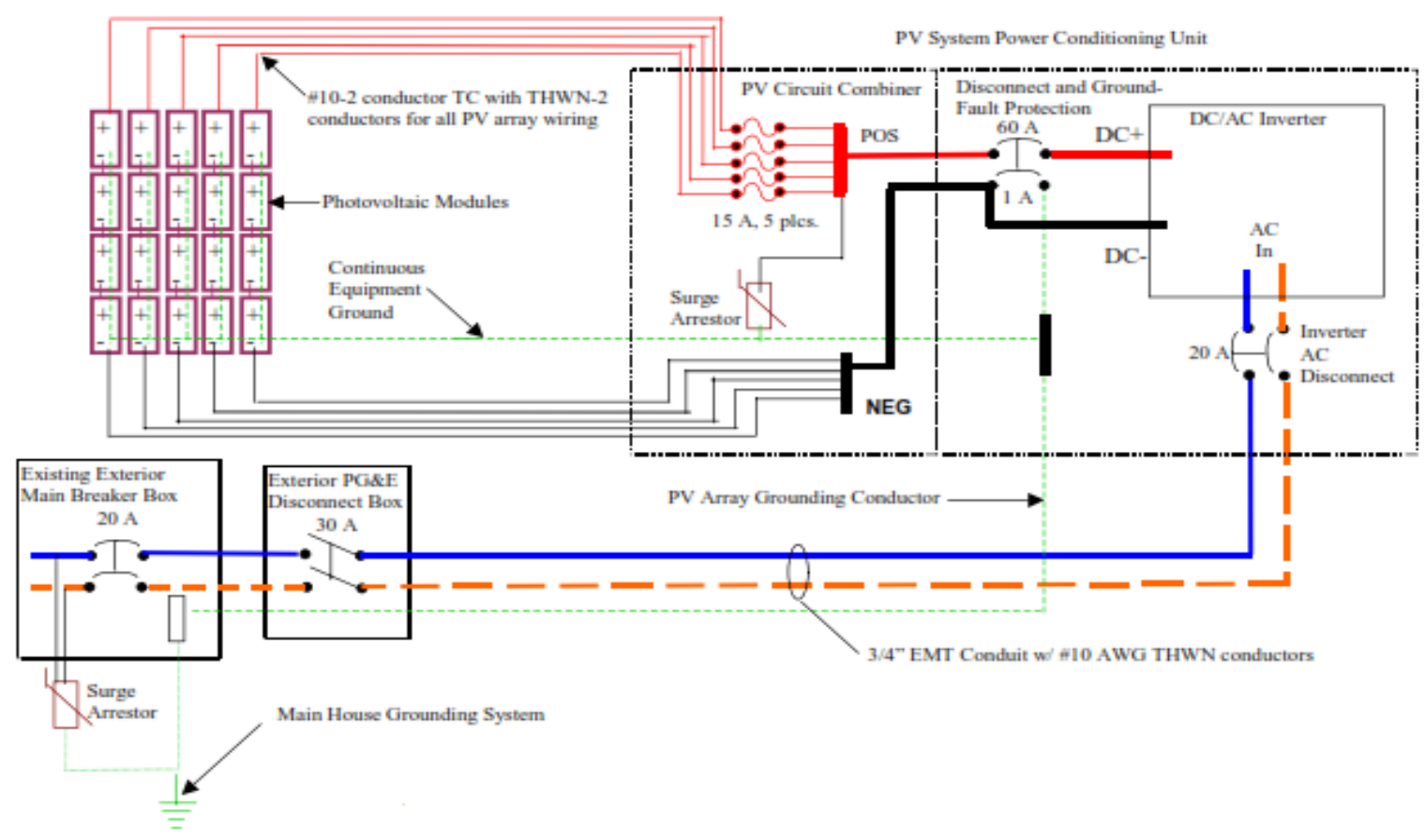

Gambar 2. Rangkaian sistem PLTS yang terhubung ke grid [6] 
Tabel 2. Moda kerusakan pada komponen PLTS [7-10]

\begin{tabular}{|c|c|c|c|}
\hline Komponen & Moda kerusakan & Efek terhadap sistem & $\begin{array}{c}\text { Failure rate } \\
\text { (failure/jam) }\end{array}$ \\
\hline \multirow{2}{*}{ Modul } & Kehilangan fungsi elektris & Tidak ada output daya & $1.35 \mathrm{E}-06$ \\
\hline & Penurunan fungsi elektris & Pengurangan output daya & $1.35 \mathrm{E}-06$ \\
\hline \multirow{6}{*}{$\begin{array}{c}\text { Junction } \\
\text { box/bypass diode }\end{array}$} & Kontak terbuka & Tidak ada output daya & $1.35299969 \mathrm{e}-07$ \\
\hline & Hubung singkat & Pengurangan output daya & $1.3529997 \mathrm{e}-07$ \\
\hline & Penurunan fungsi Kontak & $\begin{array}{l}\text { Tidak ada output daya, } \\
\text { pengurangan output daya }\end{array}$ & $1.3529997 \mathrm{e}-07$ \\
\hline & Hubung singkat pada diode & Pengurangan output daya & $6.779999 \mathrm{e}-07$ \\
\hline & Open diode & Pengurangan output daya & $6.779999 \mathrm{e}-07$ \\
\hline & Perubahan parameter pada diode & Pengurangan output daya & $6.779999 \mathrm{e}-07$ \\
\hline \multirow{3}{*}{ Connector } & Terbuka & Tidak ada output daya & $4.51 \mathrm{e}-07$ \\
\hline & Penurunan fungsi kontak & $\begin{array}{l}\text { Tidak ada output daya, } \\
\text { pengurangan output daya }\end{array}$ & $4.51 \mathrm{e}-07$ \\
\hline & Hubung singkat & Tidak ada output daya & $4.51 \mathrm{e}-07$ \\
\hline Encapsulation & Kebocoran & $\begin{array}{l}\text { Tidak ada output daya, } \\
\text { pengurangan output daya }\end{array}$ & $4.06 \mathrm{e}-06$ \\
\hline \multirow{2}{*}{ Struktur rak } & Kehilangan konfigurasi & $\begin{array}{l}\text { Tidak ada output daya, } \\
\text { pengurangan output daya }\end{array}$ & $1.22 \mathrm{e}-05$ \\
\hline & Terlepasnya bracket & $\begin{array}{l}\text { Tidak ada output daya, } \\
\text { pengurangan output daya }\end{array}$ & $1.22 \mathrm{e}-05$ \\
\hline $\begin{array}{c}\text { Grounding/proteksi } \\
\text { petir } \\
\end{array}$ & Terbuka atau tidak efektif & Pengurangan output daya & $1.62 \mathrm{e}-05$ \\
\hline \multirow{3}{*}{ Kabel udara } & Terbuka & Tidak ada output daya & $1.05 \mathrm{e}-06$ \\
\hline & Hubung singkat & Tidak ada output daya & $1.05 \mathrm{e}-06$ \\
\hline & Excessive wear & Pengurangan output daya & $1.05 \mathrm{e}-06$ \\
\hline \multirow{3}{*}{ Fuse } & Gagal membuka & Tidak ada output daya & $2.17 \mathrm{e}-07$ \\
\hline & Lambat membuka & Tidak ada output daya & $2.17 \mathrm{e}-07$ \\
\hline & Membuka tanpa dikehendaki & Tidak ada output daya & $2.17 \mathrm{e}-07$ \\
\hline \multirow{2}{*}{ Disconnect } & Terbuka tanpa dikehendaki & Tidak ada output daya & $4.51 \mathrm{e}-07$ \\
\hline & Tidak bisa membuka & Tidak ada output daya & $4.51 \mathrm{e}-07$ \\
\hline \multirow{2}{*}{ Breaker } & Terbuka tanpa dikehendaki & Tidak ada output daya & $3.28 \mathrm{e}-08$ \\
\hline & Tidak bisa membuka & Tidak ada output daya & $1.522 \mathrm{e}-06$ \\
\hline \multirow{5}{*}{ Inverter } & Gagal mentransfer daya & Tidak ada output daya & 0.000175 \\
\hline & Penurunan output & Pengurangan output daya & 0.000175 \\
\hline & Terbuka & Tidak ada output daya & $1 \mathrm{e}-07$ \\
\hline & Hubung singkat & $\begin{array}{l}\text { Tidak ada output daya, } \\
\text { pengurangan output daya }\end{array}$ & $1 \mathrm{e}-07$ \\
\hline & Perubahan parameter & Pengurangan output daya & $1 \mathrm{e}-07$ \\
\hline \multirow[t]{2}{*}{ Relay proteksi } & Gagal trip & $\begin{array}{l}\text { Tidak ada output daya, } \\
\text { pengurangan output daya }\end{array}$ & $1.4155 \mathrm{e}-06$ \\
\hline & Trip tanpa dikehendaki & Tidak ada output daya & $4 \mathrm{e}-08$ \\
\hline
\end{tabular}

Diagram Bayesian Network bagi evaluasi keandalan PLTS ditunjukkan oleh Gambar 3. Pada gambar 3, node "Gangguan pada modul seri I" merupakan suatu subgraph yang ditunjukkan oleh Gambar 4. Subgraph ini juga digunakan untuk node series II sampai V. Di Gambar 4, node "Gangguan pada PV modul 1" merupakan suatu sub matrik berikutnya yang ditunjukkan oleh Gambar 5. Gambar 5 juga mewakili modul 2 sampai 4 dari Gambar 4.

Kerusakan pada satu modul akan menyebabkan berkurangnya (hilangnya) output daya dari module yang bersangkutan. Untuk module yang terhubung seri, total daya yang dihasilkan akan sama dengan daya terkecil yang dihasilkan oleh sebuah modul dalam rangkaian 
tersebut [13], hal ini dimodelkan pada CPT dari node output modul seri I $-\mathrm{V}$, dimana output subsistem tergantung pada keluaran terkecil dari modul yang ada.

Keluaran daya dari semua string yang terhubung paralel adalah jumlah daya dari masing-masing modul [9]. Hal ini juga dimodelkan dalam CPT node "Output PV array" digambar 3, sambil memasukkan juga efek moda kerusakan pada struktur rack dan grounding dari masing-masing modul paralel.

Keandalan PLTS diberikan oleh hasil yang diberikan oleh node "Output sistem PV" pada Gambar 3. Setelah software GeNIe di jalankan maka hasil perhitungan probabilitas ketiga state PLTS ditunjukkan oleh Tabel 3.

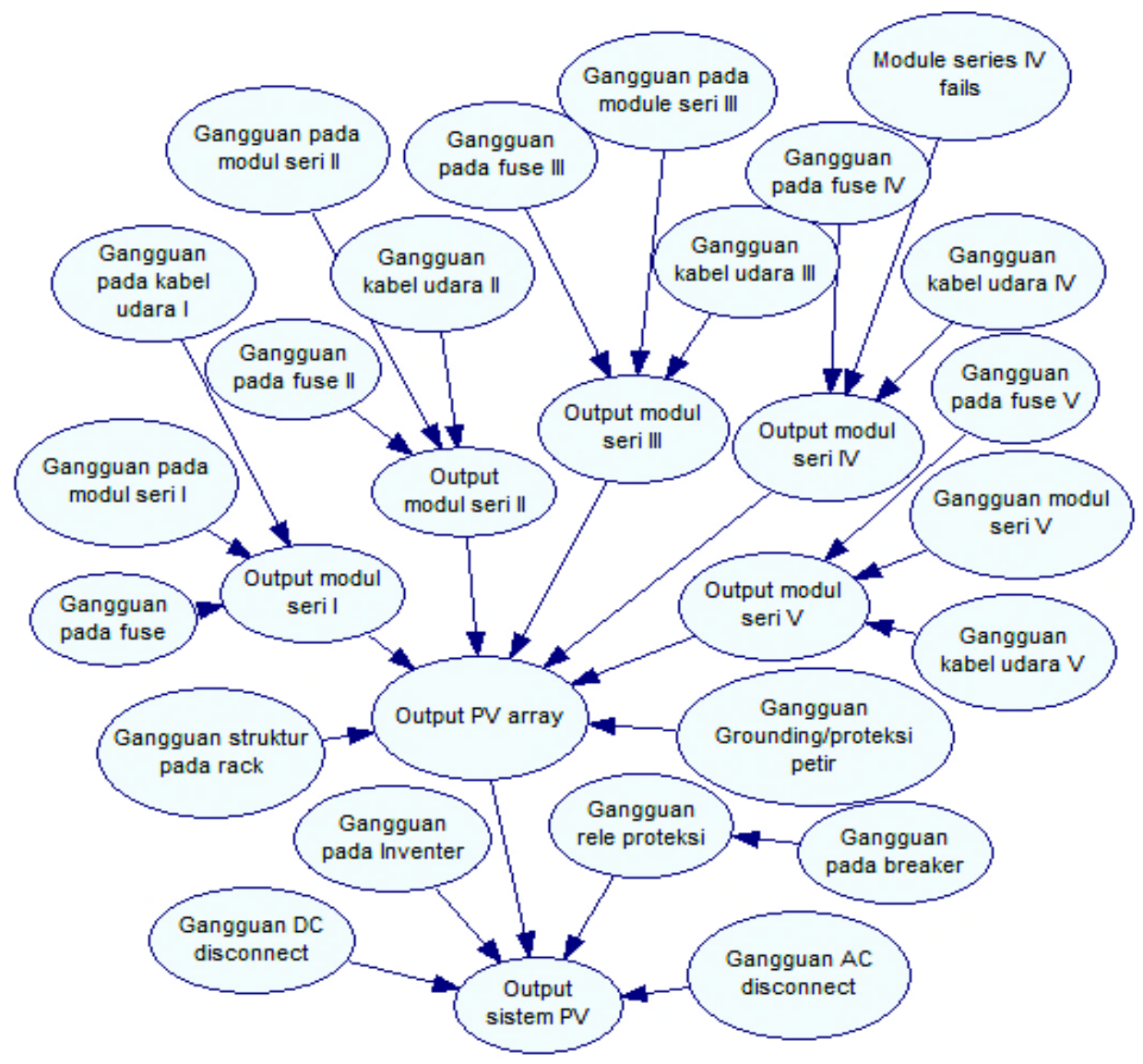

Gambar 3. Bayesian Network dari PLTS

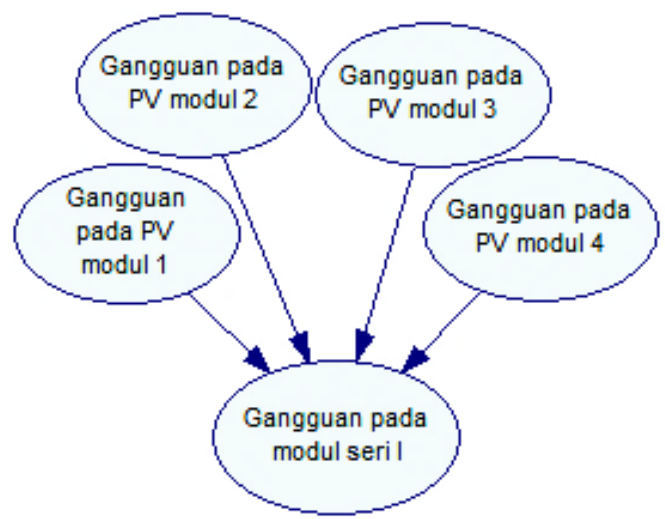

Gambar 4. Bayesian Network untuk kerusakan pada modul yang terhubung seri

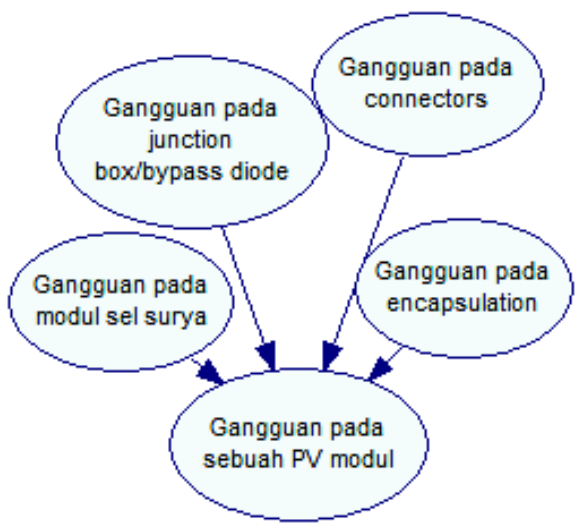

Gambar 5. Bayesian Network untuk setiap modul 
Tabel 3. Hasil perhitungan keandalan PLTS

\begin{tabular}{|c|c|}
\hline State dari PLTS & Probabilitas \\
\hline Normal & 0.99938701 \\
\hline No output & 0.00020445 \\
\hline Reduced output & 0.00040853 \\
\hline
\end{tabular}

Probabilitas di Tabel 3 Adalah probabilitas kemunculan state yang bersangkutan untuk tiap jam, saat tidak ada permasalahan dengan cahaya matahari. Terlihat kemungkinan reduced output adalah dua kali lebih tinggi frekuensinya dari pada kondisi no-output. Kondisi no output dapat terjadi setiap 4891 jam dengan asumsi sinar matahari dianggap selalu tersedia.

\section{KESIMPULAN}

Keandalan suatu PLTS ditentukan oleh kondisi cahaya matahari dan juga kesiapan peralatan PLTS untuk bekerja. Keandalan PLTS untuk bekerja (tanpa memperhitungkan kondisi cahaya matahari) telah dievaluasi. Dari hasil evaluasi diperoleh kemungkinan reduce output dari PLTS adalah dua kali lebih sering dari pada kondisi tidak ada daya keluaran. Ini terutama disebabkan karena PLTS disuplai oleh modulmodul atau string-string yang terhubung paralel. Sehingga kerusakan satu atau beberapa modul tidak akan menyebabkan PLTS kehilangan total output. Ini menjadi kelebihan tersendiri dari PLTS jika dibandingkan dengan pembangkit konvensional yang daya outputnya langsung nol jika generatornya mengalami kerusakan.

Evaluasi keandalan PLTS dalam artikel ini merupakan tahap awal dari evaluasi keandalan PLTS secara komprehensif . Evaluasi secara komprehensif akan melibat data ketersediaan sinar matahari sepanjang tahun di lokasi PLTS dibangun. Studi ini akan merupakan lanjutan dari penelitian ini.

\section{DAFTAR PUSTAKA}

[1] KESDM. (2015). Renstra KESDM 2015.

[2] K. Kananda and R. Nazir, "Konsep Pengaturan Aliran Daya Untuk PLTS Tersambung ke Sistem Grid Pada Rumah Tinggal," Jurnal Nasional Teknik Elektro, vol. 2, pp. 65-71, September 20132013.

[3] A. Bobbio, et al., "Improving the Analysis of Dependable Systems by Mapping Fault Tree into Bayesian Networks," Reliability Engineering and Safety, vol. 71, pp. 249 260, 2001.
[4] J. D. Andrews and T. R. Moss, Reliability and Risk Assessment, second ed. London: Professional Engineering Publishing, 2002.

[5] H. Langseth and L. Portinale, "Bayesian Networks in Reliability," Reliability Engineering and Safety, vol. 92, pp. 92108, 2007.

[6] H. Boundali and J. B. Dugan, "A Discretetime Bayesian Network Reliability Modelling and Analysis Framework," Reliability Engineering and Safety, vol. 87, pp. 337-349, 2005.

[7] Endecon_Engineering, "A Guide to Photovoltaic (PV) System Design and Installation," California Energy Commission, California2001.

[8] A. Colli, "Failure mode and effect analysis for photovoltaic systems," Renewable and Sustainable Energy Reviews, vol. 50, pp. 804-809, 2015.

[9] C. Honsberg and S. Bowden. (15 May 2016). Mismatch Effects in Arrays. Available:

http://www.pveducation.org/pvcdrom/mo dules/mismatch-effects-in-arrays

[10] "IEEE Recommended Practice for the Design of Reliable Industrial and Commercial Power Systems (Gold Book)," IEEE Std 493-1997 [IEEE Gold Book], pp. 1-464, 1998.

[11] A. Golnas, "PV system reliability: an operator's perspective," Photovoltaics, IEEE Journal of, vol. 3, pp. 416-421, 2013.

[12] University_of_Pitssburgh,"GeNIe Modeller 2.1," ed. www.bayesifusion.com: Bayesfusion, access April 2016.

[13] C. Honsberg and S. Bowden. (15 may 2016). Mismatch for Cells Connected in Series. Available: http://www.pveducation.org/pvcdrom/mo dules/mismatch-for-cells-connected-in$\underline{\text { series }}$

\section{Biodata Penulis}

Adrianti, menyelesaikan pendidikan S1 dan S2 di Universitas Sriwijaya dan Institut Teknologi Bandung. S3 diselesaikannya tahun 2015 di University of Strathclyde, Glasgow, Inggris. Saat ini bekerja sebagai dosen di jurusan Teknik Elektro, Universitas Andalas 